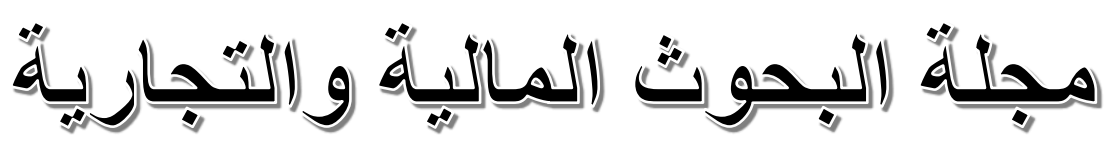

$$
\text { المجلد (22) - العدد الثالث - يوليو } 2021
$$

\title{
Audit Committee Attributes, Audit Quality, and Financial Reporting Quality: Evidence from the GCC Stock Markets
}

\section{Salah Abdel-Hafeez Mostafa Ali}

Accounting Department, Faculty of Commerce, Assiut

University, Egypt

and

Accounting Department, College of Business Administration, University of Bahrain, Bahrain

Email: samali@uob.edu.bh \& salahama@aun.edu.eg.

https://jsst.journals.ekb.eg/ رابط المجلة: 
مجلة البحوث المالية والتجارية ـ المجلد (22) - العدد الثالث - يوليو 2021

\section{ABSTRACT}

The main objective of this study is to empirically investigate whether the audit committee (AC) attributes and the quality of external auditor are associated with financial reporting quality (FRQ) of companies listed on the gulf cooperation council (GCC) countries' stock markets. To achieve the study's objectives, data was collected from a sample of 115 companies from four GCC countries during the period from 2017-2019 that represents 345 firm-year observations. Five hypotheses were tested, FRQ as dependent variable was regressed with five independent variables. For measuring the FRQ, the author adopted the qualitative approach using checklist developed by Beest, et al. 2009 sponsored by Nijmegen Center for Economics (NiCE) with limited modification based on the new amendments of IASB conceptual framework in 2018. The study findings reveal that the level of FRQ on the study sample averaged $63 \%$ while the minimum and the maximum valued $40 \%$ and $86 \%$ respectively. The findings indicate that FRQ are positively and significantly associated with the four $\mathrm{AC}$ attributes and quality of external auditor so, all hypotheses are accepted, which infer that FRQ will be enhanced if a company formed AC having, bigger size, more independence, financial experience, meetings frequently, and hiring high quality external auditor.

The findings of this study have wide implications to all stakeholders especially, investors, creditors, auditors, management, in addition to stock markets regulators and standard-sitting bodies for the role of AC attributes and external auditor on improving FRQ.

Keywords - Financial Reporting Quality, Audit Committee Attributes, Audit Quality Emerging Markets, GCC Countries. 


\section{Introduction:}

Providing high-quality and reliable information about the company's activities has been considered as the most important objectives of financial reporting (Barth et al., 2008) for stakeholders in general and for stockholders in specific, regarding the economic activities of corporations. Such information should be useful for making investment, lending, credit, and allocation of resources decisions. However, the financial reporting could be misleading which harming the decision making (Choi et al., 2010). The chairman of the SEC of U.S. has stated that investors, and capital markets have a strong desire for high-quality information about the companies' current performance and future's prospects (Clayton, J., 2020). The importance of FRQ compelled the SEC in the U.S. to be involved in four projects to enhance such quality, one of them is engagement with ACs (Teotia, S., 2020). Users mainly rely on the information provided through the company annual report which expected to be relevant, credible, reliable, and presents fairly the company's financial position and performance to enable these users in making informed decisions. (Kusnadi et al., 2016).

The FRQ is a broad concept includes both financial and nonfinancial information (Tasios \& Bekiaris, 2012). Both FASB and IASB conceptual framework set some qualitative characteristics for FRQ that includes information about the company economic status, accounting policies, and future information. Moreover, in March 2018, IASB and interpretations committee of IFRS issued the financial reporting conceptional framework which confirm "relevance, and faithful representation" as fundamental characteristics, and "comparability, understandability, verifiability, and timelines" as enhancing characteristics, So, this framework represents the best determinants of FRQ.

AC performs a vital role in supervising the application of accounting policies and selecting the auditor (Ghafran \& O'Sullivan, 2013; Hayes, 2014). It can improve $F R Q$ by restricting management to practice earnings management (Garven, 2015; Miko \& Kamardin, 2015), increasing the level of compliance with policies and regulations (Bryce 
et al., 2015; Miko \& Kamardin, 2015), improving the disclosure on the financial reporting (Abernathy et al., 2015; Tanyi \& Smith, 2015). Based on literature, AC attributes such as the size, financial and accounting qualifications, independence, and its number of meeting in addition the quality of external auditor are the most factors that affect FRQ.

Several theories support the AC in improving the FRQ. Agency theory provides explanation for the principal/agent conflict of interest which rises agency costs and the information asymmetry, as agents can adopt accounting policies that give favourable accounting results, which harm FRQ. Therefore, according to this theory principal would not trust agent and seek to find solution by having $\mathrm{AC}$ as mechanism to resolve this dilemma. Positive accounting theory with its three models provides explanations, interpretations, and predictions about how companies choose their accounting policies and how they will recognize the consequences for these alternatives (Watts \& Zimmerman, 1986). The bonus plan model predicts management/shareholders conflict of interest, as the management selects the accounting policies and use accruals to overstate earnings (Hunton et al., 2006). The debt covenant model predicts the same behaviour from management to avoid debt agreement contraventions (Dyreng et al., 2020). The political costs model predicts the adverse management behaviour to mitigate reported earnings and avoid some costs. So, positive accounting theory suggests that the intended action by management affects the quality of financial reports and companies should find mechanism to resolve this dilemma. Stakeholder theory and signalling theory can be utilized, as FRQ affects stakeholders, and through such quality the company sends a positive signal to the market.

Investigating the prior empirical research exposes that the accomplishment of $\mathrm{AC}$ in observing financial reporting process and improving FRQ can be affected by its attributes (Beasley et al., 2009; Oussii Ahmed \& Boulila Taktak, 2018; Pomeroy \& Thornton, 2008; Sharhan \& Bora, 2020; Sultana et al., 2015; Turley \& Zaman, 2007). Also, literature shows that FRQ could be measured using some attributes on earnings such as earnings management of restatement, earnings quality, timeliness, or qualitative characteristics by utilizing survey or structured checklist. This study will adopt the qualitative 
characteristics approach by constructing checklist from the conceptional framework for financial reporting as comprehensive tool for measuring FRQ.

Moreover, examining literature demonstrated that these studies conducted in developed countries (Al-Shaer et al., 2017; Bajra \& Čadež, 2018; Krishnan, 2005), or investigated the quality of integrated reporting (Chariri \& Januarti, 2017; Dilling \& Caykoylu, 2019) or includes some of AC characteristics (Umobong \& Ibanichuka, 2017) or using different measurement for FRQ (Hamdan, 2020; Khlif \& Samaha, 2016; Kibiya et al., 2016; Qinghua et al., 2007), and there is no study investigated the association between AC attributes and FRQ in the GCC countries. The current study will fill this research gap by taking all previous points in the consideration and investigates such association.

Our study objective to empirically investigates the whether the attributes of $\mathrm{AC}$ and the quality of external auditor are associated with FRQ of companies listed on the gulf cooperation council (GCC) countries' stock markets.

The contribution of this study to the accounting literature comes from utilizing a comprehensive measurement instrument for assessing FRQ. This instrument is prepared according to the qualitative characteristics, as required by IASB financial reporting conceptual framework. It contributes to practice, as one of the earliest studies that address this topic in the GCC context. Finally, this study interduces empirical evidence on the effectiveness of $\mathrm{AC}$, and audit quality in enhancing FRQ.

The organization of this paper is as follows. Section 2 comprises legal, regulatory, and cultural environment in the GCC countries. Section 3 includes the literature review and hypotheses development. Section 4 incorporates the research methodology. Section 5 contains findings, and section 6 covers the conclusion and practical implications.

\section{Legal, Regulatory and Cultural Environment in the GCC Countries:}


The GCC is a regional, political, and social organization established in 1981. It incorporates six countries, sharing similar political, cultural, language, characteristics and exhibit similar financial and capital markets (Pillai \& Al-Malkawi, 2018). The GCC consider as a significant economic power as they hold about $36 \%$ of the oil reserves in the global market (Shubita Moade, 2015). Although GCC countries mainly depend on exporting oil, the movement toward the delegation of investment created the vital needs to have a high-quality corporate governance. The GCC countries' corporate governance codes and stock markets set some regulations for creating $\mathrm{AC}$, to comprise at least 3 members, majority of them independent, and minimum number of meetings each year 4 times. In Saudi Aribia, some regulations regarding AC were issued (Capital Market Authority, Pursuant to Resolution No. 1/212/2006). According to these regulations, $\mathrm{AC}$ duties are to analyse the company's financial statements and ensuring their integrity, fairness, and transparency. In the United Arab Emirates, the AC reviews the financial reports and audit policies and regulations of the Public Joint Stock Companies (PJSC) and works closely with the external auditor of these companies to ensure that it carries out its engagement in accordance with applicable law. The corporate governance codes in Bahraini, Kuwait, Oman, and Qatar are almost identical to the as they stated same rules and duties for $\mathrm{AC}$.

All GCC countries are applying IFRS standards In Bahrain there is no local GAAP, and it has adopted IFRS Standards for all companies (Article 219 of the Commercial Companies Law). In Saudi Ariba, according to Saudi Organization for Certified Public Accountants (SOCPA). Applying IFRS are required for all listed companies starting from January 1, 2017. In the United Arab Emirates, by law (UAE Federal Law No. 2 of 2015), IFRS are required for all listed companies to be applied from July 1, 2016. In Kuwait, KAAA, as national professional accounting body, requires all listed companies to mandatory apply IFRS. In Oman, IFRS are required to be applied by all companies, as they endorsed by IASB without any amendment. In Qatar, Qatar Financial Markets Authority (QFMA) has the power to supervise and regulate the financial market (Law No. (8) Of 2012). It requires all listed companies to apply IFRS Standards. In summary, all GCC countries construct similar corporate governance codes, including 
the job, responsibility, and composition of ACs. Moreover, all these countries are applying IFRS standards, which justified combining them as one context.

\section{Literature Review and Hypotheses Development:}

The research on AC attributes, audit quality and FRQ has acquired extensive interest in the accounting literature in both developed and less developed countries. Beest et al. (2009) constructed a composite instrument to assess FRQ. The instrument built from the IASB's financial reporting conceptual framework in year 2008 and included 21 items. They tested the reliability and validity of this instrument, and it is found to be reliable and valid.

The relationship between AC and FRQ, measured by discretionary accruals, was examined by Kamolsakulchai (2015) who found positive significant relationship. In the Malaysian context, (Mohammad \& Ahmed, 2017) investigate whether AC characteristics and audit firm size have impact on FRQ, and they provide evidence that the attributes of AC affect FRQ while audit firm size has no significant effect. (Hasan et al., 2020) in Malaysian context, conducted similar study, they reported that the financial expertise and frequent meetings improved FRQ while, size and independence do not. In the African context, Umobong and Ibanichuka (2017) investigated whether AC independence and financial expertise have impact on FRQ of firms listed on Nigeria Stock Exchange from 2011-2014. They used discretionary accrual to measure FRQ and they reported positive relationship. Chariri and Januarti (2017) investigates the effect of AC attributes on integrated reporting using a sample of 58 listed companies on the Johannesburg Stock Exchanges, and they found that the level of integrated reports quality met $70 \%$ of required items. In the GCC context, Hamdan (2020) investigates the influence of three $\mathrm{AC}$ attributes on earnings quality of a sample included 23 industrial firms from the GCC during the period of 2014-2018. The study measures earnings quality using accrual accounting, and he found that size and 
مجلة البحوث المالية والتجارية ـ المجلد (22) - العدد الثالث - يوليو 2021

independence have positive impact, while $\mathrm{AC}$ number of meetings have no impact.

Reviewing the accounting literature reveals that the FRQ is critical issue for all stakeholders in making their various decisions and enhancing the market efficiency, and an effective $\mathrm{AC}$ and high-quality external auditor improve FRQ.

\subsection{AC Size and FRQ:}

AC members with large size is considered to be external resources for organizations that highly affects the behaviour of the organization, and the FRQ, as the larger number possess various skills, experiences, and power. The larger number helps AC to carry out their duties in an effective way (Allegrini \& Greco, 2013). The code of corporate governance and stock markets regulations of GCC countries requires minimum three members to form AC. Accounting literature on the association between the size of AC and FRQ provides mixed results. Yang and Krishnan (2005) found that earnings management is negatively associated with AC size, which means positive association with FRQ. Persons (2009) and Setiany et al. (2017) reported that AC with lager size enhances voluntary disclosure.

Conversely, some other research reported insignificant association between AC size and FRQ (Bamahros \& Bhasin, 2016; Hasan et al., 2020). Another study conducted by Umobong and Ibanichuka (2017) reported negative association.

Based on the above arguments, the association between $\mathrm{AC}$ size and FRQ could be positive or negative or no association, however, the majority of studies reported positive significant association and this study follows the literature so, the following hypothesis could be formulated:

H1: There is a positive significant association between audit committee size (ACSIZE) and financial reporting quality (FRQ). 


\subsection{AC Independence and FRQ:}

Bruynseels and Cardinaels (2014) define the independence of $\mathrm{AC}$ as the extent to which the $\mathrm{AC}$ is not under the pressure of management. An independent member can express an unbiased opinion than dependent members Moreover, the corporate governance codes and stock markets regulations in GCC countries pay more attention to the independence of AC members by demanded the majority of members be independent.

Most empirical studies provided positive significant association between the AC independence and FRQ. Some studies reported that earnings management as proxy for FRQ have negative association with AC independence (Bédard \& Gendron, 2010; Davidson et al., 2005; Soliman \& Ragab, 2014). Hamdan (2020) reveals that independence of $A C$ has positive association with earnings quality in GCC industrial firms. Moreover, Umobong and Ibanichuka (2017) found that higher FRQ is positively associated with the independence of $\mathrm{AC}$.

In contrast, (Kusnadi et al., 2016) do not find any evidence that the independence of $\mathrm{AC}$ enhances FRQ, as most of its members are already independent. Similar study conducted by Chariri and Januarti (2017) who found no evidence to support such association. According to the above argument the mainstream of literature supported the crucial role of $\mathrm{AC}$ independence in improving the FRQ So, this study will go with the literature and formulate the following hypothesis:

H2: There is a positive significant association between audit committee independence (ACINDE) and financial reporting quality (FRQ).

\subsection{AC Financial Expertise and FRQ:}

The expertise of $\mathrm{AC}$ members in accounting and finance can restrict engaging in undesired actions such as earnings management practices which reduce FRQ. are easily to discover any improper practices than members with less experience (Dhaliwal et al., 2010; Tanyi \& Smith, 2015). According to resource dependence theory the financial and 
accounting expertise is to provide resources to $\mathrm{AC}$ members which helps companies to gain competitive advantage, especially in FRQ. Members' financial and accounting expertise is expected to weaken the managers' ability to manipulate earnings which support the financial statement credibility. At the same time, the corporate governance codes, and stock markets regulations in GCC countries require that $\mathrm{AC}$ to include at least one member with financial experience.

Most of prior studies provided evidence that AC financial expertise has positive association with FRQ. Some studies provided evidence that AC financial expertise reduce earnings management which improve FRQ (Alzoubi Ebraheem Saleem, 2019; Badolato et al., 2014). Some other studies reported direct positive association between financial expertise of AC and FRQ (Badolato et al., 2014; Chariri \& Januarti, 2017; Hamdan, 2020; Hasan et al., 2020; Mohammad \& Ahmed, 2017; Umobong \& Ibanichuka, 2017).

On the other hand, few studies provided contradict evidence, Rainsbury et al. (2009) reported that AC financial expertise has insignificant association with FRQ while, Carrera et al. (2017) found negative association. Reviewing the literature shows that most studies support the positive association between AC financial expertise and FRQ, so this study will follow the literature and the following hypothesis can be formulated:

H3: There is a positive significant association between audit committee financial expertise (ACEXPE) and financial reporting quality (FRQ).

\subsection{AC Frequent Meetings and FRQ:}

According to agency theory AC members are committed to meet frequently for better monitoring and improving the process of financial reporting. An effective $\mathrm{AC}$ meets regularly to provide sufficient time for its members to carry out their tasks which improve the process of financial reporting (Lin \& Hwang, 2010). Greco (2011) stated that more meetings of AC help members to express their judgment about the company's accounting choices. In the same line the corporate governance codes and the stock markets regulations in GCC countries 
require $\mathrm{AC}$ to meet at least four times each year. Most of prior research provides consistent evidence regarding the association between AC meetings and FRQ. For instance, Shankaraiah and Amiri (2017) examine the association between AC meetings and FRQ in India, they found that the frequent meetings of $\mathrm{AC}$ have positive impact. Habbash and Alagla (2015) reported negative association between frequent meetings discretionary accruals. Mwangi (2018) similarly examined the impact of $\mathrm{AC}$ attributes on FRQ, and the findings reveal that frequent meetings positively affected FRQ. More recent studies (Hamdan, 2020; Hasan et al., 2020) confirm the same previous findings. In contrast, a few studies reported no association (Bedard et al., 2004), and (Yang \& Krishnan, 2005) or reported insignificant association (Bamahros \& Bhasin, 2016; Habbash \& Alagla, 2015). Reviewing the literature ensure that the mainstream of studies support the positive association between AC number of meetings and FRQ. Based on the above judgement in the literature the following hypothesis could be formulated:

H4: There is a positive significant association between audit committee frequent meetings (ACMEET) and financial reporting quality (FRQ).

\subsection{Audit Quality and FRQ:}

Auditors can improve processes of financial reporting which will be resulted on high quality financial reports. The size of audit firm has significant impact on audit quality (Choi et al., 2010; Francis \& Yu, 2009) so, big four auditors are more capable and more independent and can afford superior quality audits than the non-big four auditors. So, auditors with a bigger client base hold higher reputation, so they would ensure a better audit quality that reflecting in a higher FRQ. Prior study, Kamolsakulchai (2015) reported positive association between big size audit firm and quality of disclosure as measurement for FRQ. Similar results reached by Gaynor et al. (2016) as they found positive audit quality improved earnings quality. 
مجلة البحوث المالية والتجارية ـ المجلد (22) - العدد الثالث - يوليو 2021

On the other hand, a few studies provided different results, for instance, Mohammad and Ahmed (2017) reported no significant association between the size of audit firm and FRQ.

Based on the above judgement most literature supports that the quality of external auditor is positively significantly associated with FRQ so, and following hypothesis could be formulated:

H5: There is a positive significant association between audit quality (AUDQUL) and financial reporting quality (FRQ).

\section{Research Design:}

\subsection{Sample}

The study sample include 115 companies listed on the stock markets of four GCC countries (Saudi Aribia, United Arab Emiratis, Kuwait, and Bahrain) during the period from 2017-2019 that represents 345 firmyear observations. Companies to be included in the sample must have the following criteria: have sufficient data regarding the $\mathrm{AC}$ attributes and financial reporting. Are not banking and insurance companies because of having specific industry characteristics and different regulations imposed by the central banks and AAOIFI standards.

The data needed were collected from several sources such as the sock markets of GCC countries, companies web-sits, companies annual reports, and other web-sits such as Mubashir and Tadawul. The reason behind selecting the years 2017, 2018, and 2019 is the availability of data, especially data regarding the details of $\mathrm{AC}$ attributes.

Table (1) below provide the number of firm-year observations in each year totaling of $\mathbf{3 4 5}$ firm-year observations after excluding 5 companies which provide non-sufficient data.

Table 1: Firm-year observations over the period of empirical investigation:

\begin{tabular}{|l|c|c|c|c|}
\hline Numbers/Years & 2017 & 2018 & 2019 & Total \\
\hline - number of companies in GCC countries & 120 & 120 & 120 & $\mathbf{3 6 0}$ \\
\hline - Companies excluded & 5 & 5 & 5 & $\mathbf{1 5}$ \\
\hline - Firm-year observations & 115 & 115 & 115 & $\mathbf{3 4 5}$ \\
\hline
\end{tabular}


Audit Committee Attributes, Audit Quality, and Financial

Reporting Quality... Dr. Salah Abdel-Hafeez Mostafa Ali

Table 2: The classification of sample according to industry type:

\begin{tabular}{|c|c|c|}
\hline Industry Type & No. & $\%$ \\
\hline - Industrial (IND) & 25 & 21.7 \\
\hline - $\quad$ Technology and Telecommunication (TEC and TEL) & 9 & 7.9 \\
\hline - $\quad$ Energy, Oil, and Gas (ENG \& OIL \& GAS) & 11 & 9.6 \\
\hline - $\quad$ Materials and Constructions (MAT \& CON) & 25 & 21.7 \\
\hline - OTHERS & 45 & 39.1 \\
\hline Total & 115 & 100 \\
\hline
\end{tabular}

\subsection{Measuring Financial Reporting Quality (FRQ): The Dependent Variable}

Numerous studies employed indirect approaches to measure FRQ. These approaches concentrated on some attributes that affect FRQ such as earnings management, earnings restatements, and timeliness (AlShaer et al., 2017; Bajra \& Čadež, 2018; Dechow \& Dichev, 2002; Dhaliwal et al., 2010; Hasan et al., 2020; Kamolsakulchai, 2015; Kusnadi et al., 2016; Mohammad \& Ahmed, 2017). Hence, these measurements could provide partial signs for the FRQ, as none of them enable a comprehensive measurement for FRQ. Oji and Ofoegbu (2017) utilized structured questionnaire which could be biased instrument. Some other studies employed content analysis, for example, Cooray et al. (2020); Dilling and Caykoylu (2019) measure the quality of integrated reports by used qualitative text analysis and assigning scores based on information disclosed in the integrated reports. However, these studies focussed integrated financial reporting. Beest et al. (2009) conducted study - sponsored by Nijmegen Center for Economics (NiCE) - and they developed comprehensive 21-items checklist for measuring FRQ based on the information qualitative characteristics as defined by the financial reporting conceptual framework of IASB (2008). Utilizing qualitative characteristics is superior as they measure all values and attributes of FRQ such as predictive, confirmatory, verifiability, neutrality, completeness, understandability consistency, comparability, timeliness, and other non-financial information. 
This study will adopt Beest et al. (2009) with limited modification based on the new amendments of the financial reporting conceptual framework issued by IASB in 2018. To measure FRQ according to this comprehensive instrument, standardized scores for both qualitative characteristics was computed. The instrument comprises index of 21 items, each item is measured by 5 degree-scale, and the maximum total score for any company is totalling 105 . The score for each company is calculated and divided by 121 to be measured as percentage represents the level of FRQ. The validity and reliability of the adopted instrument were tested using Cronbach's alpha and Krippendorff's alpha and the results of these tests were 0.75 and 0.79 respectively, which are above the required score 0.70 . This suggests that score of measuring FRQ is valid and reliable.

\subsection{The Research Models}

This study investigates the association between $\mathrm{AC}$ attributes, audit quality, and FRQ. To measure the association between the independent variables ACSIZE, ACINDE, ACEXPE, ACMEET, and AUDQUL and the dependent variable FRQ, the following model was formulated:

FRQ $_{i, t}=a 0_{i, t}+a_{1}$ ACSIZE $_{i, t}+a_{2}$ ACINDE $_{i, t}+a_{3}$ ACEXPE $_{i, t}+a_{4}$ ACMEET ${ }_{i, t}+a_{5} A A U D Q U L_{i, t}+e_{i, t}$

Whereas:

$F R Q_{i, t}$ "is an measurement of financial reporting quality score for company i, year t.".

$\operatorname{ACSIZE}_{i, t}$ "is number of $\mathrm{AC}$ members".

$A_{C I N D E}, t$, "is the independence of AC members for company $i$, t.".

$A C E X P E_{i, t}$ "is the financial expertise of $\mathrm{AC}$ members for company $\mathrm{i}$, year t.".

$A C M E E T_{i, t}$ "is the AC number of meetings for company i, year t."

$A U D Q U L_{i, t}$ "is the audit quality for company $i$, year t."

By adding some corporate characteristics as control variables to the model, it will be formulated as following: 
Audit Committee Attributes, Audit Quality, and Financial

Reporting Quality... Dr. Salah Abdel-Hafeez Mostafa Ali

$F R Q_{i, t}=a 0_{i, t}+a_{1} A_{C S I Z E}{ }_{i, t}+a_{2} A_{C I N D E} E_{i, t}+a_{3} A C E X P E_{i, t}+a_{4} A C M E E T$ ${ }_{i, t}+a_{5}$ AAUDQUL $_{i, t}+a_{6}$ FSIZE $_{i, t}+a_{7}$ FROE $_{i, t}+a_{8}$ FLEV $_{i, t}+a_{9}$ FLIST $_{i, t}$ $+a_{10}$ INDTYPE $_{i, t}+e_{i, t}$

Whereas:

FSIZE $_{i, t}$ "is the company size".

$F R O E_{i, t}$ "is the company return on equity".

$F L E V_{i, t}$ "is the company leverage".

$F_{\text {FIST }}{ }_{i, t}$ "is the company listing on other stock markets".

$I_{N D T P E}, t$, “is the type of industry sector for each company".

\subsection{Variables}

Three types of variables used in this study. The first type FRQ as dependent variable, the second type comprise AC, size (ACSIZE), independence (ACINDE), financial experience (ACEXPE), frequent meetings (ACMEET), and audit quality (AUDQUL). The third type is the control variables named firm size (FSIZE), firm performance (FROE), firm leverage (FLEV), firm listing on other stock markets (FLIST), and the industry type (INDTYPE). Table 3 below summarizes all variables used in the study model and their related proxies. 
Table 3: Definitions of variables used in the empirical analysis:

\begin{tabular}{|c|c|c|}
\hline Variables & $\begin{array}{l}\text { Predicted } \\
\text { Sign }\end{array}$ & Definitions \\
\hline $\begin{array}{l}\text { Dependent Variables: } \\
\text { FRQ } \\
\text { Independent variables: } \\
\text { 1- AC size (ACSIZE). } \\
\text { 2- AC independence (ACINDE). } \\
\text { 3- AC financial and accounting } \\
\text { experience (ACEXPE). } \\
\text { 4- AC number of meetings each year } \\
\text { (ACMEET). } \\
\text { 5- Audit quality (AUDQUL). } \\
\text { Control Variables: } \\
\text { 1- Company size (FSIZE) } \\
\text { 2- Company performance (FROE) } \\
\text { 3- Company leverage (FLEV) } \\
\text { 4- Company listing (FLIST) } \\
\text { 5- Industry sector type (INDTYPE) }\end{array}$ & $\begin{array}{c}+ \\
+ \text { or - } \\
+ \text { or - } \\
\quad+ \\
+ \text { or - }\end{array}$ & $\begin{array}{l}\text { - "number of AC members. } \\
\text { - \% of non-executive members to total of } \\
\text { members". } \\
\text { - "\% of AC members with financial and } \\
\text { accounting experience to total of } \\
\text { members". } \\
\text { - "Number of AC meetings each year". } \\
\text { - "(1) if audit external auditor is one of the } \\
\text { big } 4 \text { and (0) otherwise". } \\
\text { - "The total assets natural logarithm". } \\
\text { - "Company net profit to total equity". } \\
\text { - "Company total liabilities/total assets". } \\
\text { - "(1) If the company is listed outside the } \\
\text { country stock market and (0) otherwise". } \\
\text { - "(1) if firm industrial sector, (2) if } \\
\text { technological and telecommunication, (3) } \\
\text { if energy or oil or gas, (4) if materials and } \\
\text { constructions, and (5) if others". }\end{array}$ \\
\hline
\end{tabular}

Notes: 1- Information on variables was computed at the end of 2019 financial period (US\$1 = EGP 15.99) or the average of three years from 2017 to 2019.; 2- Predicted signs of independent and control variable were based on their expected effects on FRQ.

\subsection{Hypotheses Testing:}

For testing the hypotheses, financial reporting quality (FRQ) as dependent variable was regressed on five independent variables and five control variables as shown in table 3 above. The regression results in the findings section show whether each of the five hypotheses accepted or rejected. 


\section{FINDINGS}

Three sub-sections including "descriptive statistics", "univariate analysis" and "multivariate analysis" are presented under this section. They present dissection the findings and testing the hypotheses.

\subsection{Descriptive Statistics}

Tables 4 and 5 below report descriptive statistics for both nominal (categorized) variables interval or ratio variables. As is shown in table 3 , about $42 \%$ of listed companies in the GCC countries stock market hire one of the big four audit firm while the remaining $58 \%$ hire auditor not from the big four, which indicates that the quality of external auditing. Also, about $18 \%$ of these companies are listed on other stock markets, as GCC countries stock markets regulations encourage companies to be listed in other stock markets.

Tables (4): Descriptive statistics for nominal (categorized) variables.

\begin{tabular}{|c|c|c|c|}
\hline Characteristics & Category & Number & $\%$ \\
\hline \multirow{2}{*}{$\begin{array}{l}\text { Audit quality } \\
\text { (ADUQUL) }\end{array}$} & BIG4 & 48 & 41.7 \\
\hline & NBIG4 & 67 & 58.3 \\
\hline \multicolumn{2}{|l|}{ Total } & 115 & $\% 100$ \\
\hline & FLIST & 21 & 18.3 \\
\hline $\begin{array}{l}\text { List in other foreign } \\
\text { stock market (FLIST) }\end{array}$ & FNLIST & 94 & 81.7 \\
\hline \multicolumn{2}{|l|}{ Total } & 115 & $100 \%$ \\
\hline Industry type & IND & 25 & 21.7 \\
\hline \multirow[t]{4}{*}{ (INDTYPE) } & TEC and TEL & 9 & 7.9 \\
\hline & ENG \& OIL \& GAS & 11 & 9.6 \\
\hline & MAT \& CON & 25 & 21.7 \\
\hline & OTHERS & 45 & 39.1 \\
\hline \multicolumn{2}{|l|}{ Total } & 115 & $100 \%$ \\
\hline
\end{tabular}

Table 5 below shows the mean, minimum, maximum, and standard deviation of the dependent variable, four independent variables and 
three control variables. The average of FRQ for companies listed on the GCC countries stock markets is about $63 \%$ while the maximum is $86 \%$ and the minimum is $40 \%$ of their earnings. These results are little far from Beest, et al, (2009) results as they reported an average of FRQ to be about $70 \%(3.5 / 5)$. The reason behind the difference in the FRQ score could be related to context as this study conducted in developed countries, the period of study, and the applied accounting standards. These results indicated that the FRQ in the GCC companies needs to be improved. The average score of FRQ based on the fundamental characteristics (FRQFC) and the average score of FRQ based on the enhancing characteristics (FRQEC) are very close, as their values are 64.8\% and $63.9 \%$ respectively, which suggests that both qualitative characteristics are given same consideration. The average number of members for AC size (ACSIZE) is about 4.5 with minimum of 3 and maximum of 7 members. The average level of $\mathrm{AC}$ independence (ACINDE) is about $62 \%$ with minimum of $20 \%$ and maximum of $100 \%$. Regarding the AC financial and accounting expertise (ACEXPE), the average level is about $39 \%$ with minimum of $33 \%$ and maximum of 86\%. AC frequent meetings (ACMEET) are averaged about 7 meetings each year with minimum of 4 and maximum of 14 . The results related to AC attributes are mostly consistent with the codes of corporate governance and the regulations of stock markets in the GCC countries, as the minimum of $\mathrm{AC}$ size not less than 3, members should be independent, at least one of them has financial expertise, and they meet at least 4 times a year. Only the independence level needs to be improved, as some $\mathrm{AC}$ members are executive.

Some more information regarding the average, maximum, minimum, and standard deviation of FSIZE, FROE, FLEV, are shown in table 5 below. 
Audit Committee Attributes, Audit Quality, and Financial Reporting Quality... Dr. Salah Abdel-Hafeez Mostafa Ali

Tables (5): Descriptive statistics for interval (ratio) variables.

\begin{tabular}{|c|c|c|c|c|c|}
\hline Variables & No. & Minimum & Maximum & Mean & Std. Deviation \\
\hline$F R Q(\%)$ & 115 & 0.40 & 0.86 & 0.6301 & 0.18734 \\
\hline ACSIZE (No.) & 115 & 3.00 & 7.00 & 4.5478 & 1.55170 \\
\hline ACINDE (\%) & 115 & 0.20 & 1.00 & 0.6155 & 0.24627 \\
\hline ACMEET (No.) & 115 & 4.00 & 14.00 & 7.2609 & 3.25007 \\
\hline $\operatorname{ACEXPE~(\% )~}$ & 115 & 0.33 & 0.86 & 0.3880 & 0.25628 \\
\hline FRQFC (\%) & 115 & 0.49 & 0.88 & 0.6486 & 0.12668 \\
\hline FRQEC (\%) & 115 & 0.47 & 0.87 & 0.6390 & 0.10296 \\
\hline FSIZE \$ & 115 & 6932701.61 & 11881755402.00 & 510844371.56 & 223621674.37 \\
\hline FROE (\%) & 115 & \begin{tabular}{|l|}
-160.00 \\
\end{tabular} & \begin{tabular}{||l|}
245.00 \\
\end{tabular} & 34.6046 & 23.07956 \\
\hline FLEV (\%) & 115 & 0.07 & 38.56 & 6.6760 & 5.79812 \\
\hline
\end{tabular}

\subsection{Univariate Analysis}

This section presents the relationship between each variable and all other variables. Pearson correlation coefficients is presented in table 6 below which shows some the correlations between all variables. For instance, a positive and significant correlation was found at $P<0.01$ between FRQ and two independent variables namely, AC financial experience (ACEXPE) and AC meetings (ACMEET). Moreover, the relationship between $F R Q$ and $A C$ independence (ACINDE) is positive and significant at $P<0.05$, while the relationship with $A C$ size (ACSIZE) is positive and significant at $P<0.10$. These results suggest that the most effective attributes of $A C$ on FRQ are the financial and accounting expertise and the AC meetings at $99 \%$ level of confidence. The AC independence is effective attribute but at $95 \%$ level of confidence, while AC size is effective at $90 \%$ level of confidence.

On the other hand, the relationship between FRQ and the company size as control variable (FSIZE) is positive and significant at $\mathbf{P}<0.05$, while the relationship with the other two control variables named company performance (FROE) and company leverage (FLEV) is not significant. These results suggest that the larger companies have higher financial reporting quality than smaller companies. Also, the company performance and leverage are not significantly related to FRQ. 
مجلة البحوث المالية والتجارية ـ المجلا (22) - العدد الثالث - يوليو 2021

Table (6): Person Correlation Matrix

\begin{tabular}{|c|c|c|c|c|c|c|c|c|c|c|}
\hline & FRQ & FRQFC & FRQEC & ACSIZE & ACINDE & ACMEET & ACEXP & FSIZE & FROE & FLEV \\
\hline FRQ & 1 & & & & & & & & & \\
\hline FRQFC & $0.957^{* *}$ & 1 & & & & & & & & \\
\hline FRQEC & $0.964^{* *}$ & $0.845^{* *}$ & 1 & & & & & & & \\
\hline ACSIZE & $0.233^{*}$ & $0.229^{*}$ & $0.205^{*}$ & 1 & & & & & & \\
\hline ACINDE & $0.397^{* *}$ & $0.444^{* *}$ & $0.323^{* *}$ & $0.557^{* *}$ & 1 & & & & & \\
\hline ACMEET & $0.589^{* * *}$ & $0.611^{* * *}$ & $0.523^{* * *}$ & $0.582^{* *}$ & $0.538^{* *}$ & 1 & & & & \\
\hline ACEXP & $0.653^{* * *}$ & $0.368^{* * *}$ & $0.320^{* * * *}$ & $0.288^{*}$ & $0.269^{*}$ & 0.157 & 1 & & & \\
\hline FSIZE & $0.292^{* *}$ & $0.295^{* *}$ & $0.282^{* * *}$ & $0.371^{* *}$ & 0.105 & 0.070 & $0.206^{*}$ & 1 & & \\
\hline FROE & 0.147 & 0.153 & 0.130 & 0.108 & 0.114 & 0.112 & 0.141 & 0.012 & 1 & \\
\hline FLEV & 0.018 & 0.027 & 0.008 & -0.110 & 0.124 & -0.094 & 0.081 & 0.037 & 0.037 & 1 \\
\hline
\end{tabular}

*** Correlation is significant at $\mathrm{P}<0.01$ (2-tailed).

** Correlation is significant at $\mathrm{P}<0.01$ (2-tailed).

* Correlation is significant at $\mathrm{P}<0.01$ (2-tailed). 


\subsection{Multivariate Analysis (Regression Analysis and Hypotheses Testing}

This section is devoted to regression analysis and hypotheses testing. Table 7 below presents the regression model results that used to identify which of the independent and control variables included in the regression model contribute to the prediction of the dependent variable. The regression model utilized to test the study hypotheses. This model includes FRQ as dependent variable and five independent variables named ACSIZE, ACINDE, ACEXPE, ACMEET, and AUDQUL. Also, it includes five control variables related to the corporate characteristics named FSIZE, FROE, FLEV, FLIST, and INDTYPE. These variables are explained in the methodology section.

Table 7 below shows the explanatory power of the study model measured by adjusted $R^{2}$. The value of adjusted $R^{2}$ in the model is $72 \%$ which ranked this model as powerful one comparing to the similar studies. For instance, Qinghua et al. (2007) reported $29.7 \%$ adjusted $\mathbf{R}^{2}$ while, Beest et al. (2009) reported $21.6 \%$ in their model. Kamolsakulchai (2015) reported three adjusted $R^{2}$ for three different sectors, and the highest one was $35.13 \%$ in the technology sector. Mohammad and Ahmed (2017) reported adjusted $R^{2}$ of $77.09 \%$ but they measure FRQ by earnings management. Bajra and Čadež (2018) reported $R^{2}$ of $35.5 \%$, while Hasan et al. (2019) reported only adjusted $8.4 \mathbf{R}^{2}$. In a study conducted in the GCC countries, Hamdan (2020) reported adjusted $\mathbf{R}^{2}$ $38.5 \%$. Comparing our study model with the other modules reveals that this model is one of the strongest models, as included all related dependent and control variables.

Moreover, the model in general is significant at $\mathbf{p}<0.01$, as $\mathbf{F}$. Sig. valued 0.000 which indicates that the FRQ is explained by AC attributes, audit quality, and some other control variables, as they shown in table 7 below. The explanatory power of each one of the independent and control variables is shown in table 7 below in details. 
Table (7): Multiple regression analysis for factors associated with FRQ.

\begin{tabular}{|c|c|c|c|c|c|}
\hline Predictors & B & Beta & $\mathrm{T}$ & Sig. T & Effect \\
\hline ACSIZE & 0.074 & 0.254 & 1.758 & 0.071 & $*$ \\
\hline ACINDE & 0.082 & -0.295 & 2.246 & 0.016 & $* *$ \\
\hline ACMEET & 0.093 & 0.287 & 3.166 & 0.046 & $* *$ \\
\hline ACEXPE & 0.119 & 0.413 & 5.184 & 0.004 & $* * *$ \\
\hline AUDQUL (BIG4) & 0.093 & 0.424 & 2.547 & 0.035 & $* *$ \\
\hline FSIZE & -1.284 & -0.026 & -0.422 & 0.094 & $*$ \\
\hline $\mathrm{ROE}$ & -1.940 & -0.017 & -0.314 & 0.754 & NS \\
\hline FLEV & 0.000 & -0.021 & -0.394 & 0.694 & NS \\
\hline LIST & 0.075 & 0.314 & 5.172 & 0.000 & $* * *$ \\
\hline INDTYP & -0.013 & -0.051 & -0.922 & 0.159 & $\mathrm{NS}$ \\
\hline \multicolumn{3}{|l|}{ Constant } & \multicolumn{3}{|l|}{11.142} \\
\hline \multicolumn{3}{|l|}{$\mathrm{R}^{2}$} & \multicolumn{3}{|l|}{0.754} \\
\hline \multicolumn{3}{|l|}{ Adj. $\mathrm{R}^{2}$} & \multicolumn{3}{|l|}{0.72} \\
\hline \multicolumn{3}{|l|}{$\mathrm{F}$} & \multicolumn{3}{|l|}{21.949} \\
\hline \multicolumn{3}{|l|}{ F Sig. } & \multicolumn{3}{|l|}{$0.000 * * *$} \\
\hline
\end{tabular}

$* * * \mathrm{P}<0.01, * * \mathrm{P}<0.01, * \mathrm{P}<0.01$.

According to table 7 above, ACSIZE has positive and significant association with FRQ at $p<0.10$ as the value of Seg. $T$ is 0.071 . This result indicates that larger number of $\mathrm{AC}$ improves the FRQ, as the larger number provides more power to $\mathrm{AC}$, helps the committee to carry out its duties in an effective way, as larger members possess various skills and experiences. This result provides reasonable explanation for requirements of corporate governance codes and stock markets regulations in the GCC countries which determined such number to be at least three.

This result confirms that the bigger size of AC, the higher FRQ so, null hypothesis will reject the as "There is a negative significant association between audit committee size (ACSIZE) and financial reporting quality (FRQ)" and accept the alternative hypothesis that "There is a positive significant association between audit committee size (ACSIZE) and financial reporting quality (FRQ)". Moreover, these results provide evidence that the association is positive.

Our results are consistent with numerous studies in the literature on this regard (Hamdan, 2020; Kamolsakulchai, 2015; Setiany et al., 2017; Yang \& Krishnan, 2005), as these studies reported positive significant 
association ACSIZE and FRQ. In contrast, this study is not consistent with some other studies which reported insignificant association between ACSIZE and FRQ (Hasan et al., 2019; Mohammad \& Ahmed, 2017; Soliman \& Ragab, 2014; Umobong \& Ibanichuka, 2017; Xie et al., 2003). The nonconsistency of some studies can be explained by several reasons, as these studies conducted in different contexts, dissimilar sample sizes, using various proxies for measuring FRQ such as earnings quality, decreasing of earnings management, improving voluntary disclosure.

Regarding the association between ACINDE and FRQ, the multiple regression analysis in table 7 above presents positive and significant association at $p<0.05$ as the value of Seg. $T$ is 0.016 . This result indicates that the FRQ is higher at companies having more independence $\mathrm{AC}$, as such independence provides members with more power and autonomy to express their opinion, which will be reflected on the financial reporting transparency and reduced information asymmetry. This result ensures that FRQ will be improved if the AC possess more independence. Hence, the null hypothesis will be rejected as "There is a negative significant association between audit committee independence (ACINDE) and financial reporting quality (FRQ)" and accept the alternative hypothesis that "There is a positive significant association between audit committee independence (ACINDE) and financial reporting quality (FRQ)".

several studies in the literature are consistent with our study on this regard, as the mainstream of empirical studies reported positive and significant association between ACINDE and FRQ measured in various proxies. Soliman and Ragab (2014) provide evidence that earnings management is negatively associated with ACINDE. Hamdan (2020) reveals that the quality of earnings has positive and significant association with more ACINDE. Some other studies found that ACINDE is associated with more voluntary disclosure (Akhtaruddin \& Haron, 2010; Umobong \& Ibanichuka, 2017) reported positive significant association between ACINDE and higher FRQ. Conversely, this study is not consistent with other few studies (Chariri \& Januarti, 2017; Kusnadi et al., 2016) who do not find evidence that ACINDE 
enhances FRQ. The explanation behind these studies' results that AC formed from independent members.

The association between ACEXPE and FRQ is shown in the multiple regression analysis in table 7 above which presents positive and significant association at $p<0.01$ as the value of Seg. $T$ is 0.004 . This result indicates that $F R Q$ is higher at companies having more members with financial and accounting expertise, as such expertise helps members to detect inappropriate accounting and auditing practices and restricts managers from practicing in undesired activities such as earnings management which reduce FRQ.

This result ensures that FRQ will be improved if members of $\mathrm{AC}$ possess more experience in finance and accounting. Hence, the null hypothesis will be rejected as "There is a negative significant association between audit committee financial expertise (ACEXPE) and financial reporting quality (FRQ)" and the alternative hypothesis will be accepted as: "There is a positive significant association between audit committee financial expertise (ACEXPE) and financial reporting quality (FRQ)".

Our findings are consistent with the mainstream of prior research that reported significant and positive association between ACEXPE and FRQ measured in various proxies. (Badolato et al., 2014; Chariri \& Januarti, 2017; Hamdan, 2020; Hasan et al., 2019; Hasan et al., 2020; Hayes, 2014; Kusnadi et al., 2016; Mohammad \& Ahmed, 2017; Umobong \& Ibanichuka, 2017). Other stream of research found that ACEXPE reduces earnings management which improve FRQ (Alzoubi Ebraheem Saleem, 2019; Badolato et al., 2014). Our study is not consistent with few studies, Rainsbury et al. (2009) reported insignificant association between the ACEXPE and FRQ, while Carrera et al. (2017) indicates that increasing financial accounting expertise decreases FRQ. The explanation of this contradictory results as these studies conducted before issuing any regulations or rules for $\mathrm{AC}$.

The association between FRQ and AC frequent meetings (ACMEET) is shown in the multiple regression analysis in table 7 above which presents positive and significant association at $p<0.05$ as the value of Seg. $T$ is 0.046. This result indicates that FRQ is higher at companies having active AC members, as such activeness provides members with sufficient time to perform their obligations. 


\section{Audit Committee Attributes, Audit Quality, and Financial Reporting Quality... Dr. Salah Abdel-Hafeez Mostafa Ali}

This result ensures that FRQ will be improved if the AC meets frequently and more times. Hence, the null hypothesis will be rejected as "There is a negative significant association between audit committee frequent meetings (ACMEET) and financial reporting quality (FRQ)" and the alternative hypothesis will be accepted as: "There is a positive significant association between audit committee frequent meetings (ACMEET) and financial reporting quality (FRQ)".

Our findings are consistent with literature as most studies reported positive significant association between ACMEET and FRQ measured in various proxies (Habbash \& Alagla, 2015; Hamdan, 2020; Hasan et al., 2019; Hasan et al., 2020; Lin et al., 2006; Mwangi, 2018; Shankaraiah \& Amiri, 2017). Our results confirmed the findings of previous studies as more AC meetings is positively affected FRQ. Our study in not consistent with some studies as they reported insignificant association (Bamahros \& Bhasin, 2016; Yang \& Krishnan, 2005). These inconsistent results might back to using old data, at that time no regulations for $\mathrm{AC}$ were established.

The association between FRQ and audit quality (ADUQUL) is shown in the multiple regression analysis in table 7 above which presents positive and significant association at $p<0.05$ as the value of Seg. $T$ is 0.035 . This finding reveals that FRQ is higher at companies hiring one of the big four auditors, as they are more competent and more independent than non-big four auditors. moreover, big four audit firms hold higher reputation, so they would ensure a superior audit which improves FRQ. This result ensures that FRQ will be improved if the companies have high quality audit by hiring one on the big four audit firms. Hence, the null hypothesis will be rejected as "There is a negative significant association between audit quality (ADUQUL) and financial reporting quality (FRQ)" and the alternative hypothesis will be accepted as: "There is a positive significant association between audit quality (AUDQUL) and financial reporting quality (FRQ)".

Our results are consistent with (Inaam et al., 2012; Soliman \& Ragab, 2014) who reported that audit quality has negative significant association with earnings management, and Kamolsakulchai (2015) who 
documented that the level of disclosure is positively associated with the bigger audit firm size, and Gaynor et al. (2016) as they found that quality of earnings is positively associated with ADUQUL. Our study in not consistent with (Mohammad \& Ahmed, 2017) who reported insignificant association with FRQ. The inconsistent in these results could be inferred to the difference in the research context, sample size, and research period.

Moreover, table 7 above shows positive between FRQ and some other control variables. For instance, the company size (FSIZE) has positive and significant association with $F R Q$ at $p<0.10$ as the value of Seg. $T$ is 0.094. This result suggests that the bigger size companies provide higher quality of financial reporting. Further, listing the company in other stock markets (FLIST) is positively and significantly associated with FRQ at $p<0.01$ as the value of Seg. $T$ is 0.000 . this result suggests that companies which listing their stocks in other stock markets must comply with the other stock markets regulations, which be reflected on high quality financial reporting.

In summary our results indicate that FRQ has positive and significant association with four attributes of $\mathrm{AC}$ and audit quality thus, all five null hypotheses are rejected, and the alternative hypotheses are accepted as there is a positive significant association between FRQ as dependent variable and five independent variables named, ACSIZE, ACINDE, ACEXPE, ACMEET, and AUDQUL.

\section{Conclusions and Practical Implications}

The main objective of this study is to empirically investigate whether the attributes of $\mathrm{AC}$ and the quality of external auditor are associated with financial reporting quality (FRQ) of companies listed on the gulf cooperation council (GCC) countries' stock markets. To achieve the study's objectives, data was collected from a sample of 115 companies from four GCC countries during the period from 2017-2019 that represents 345 firm-year observations. Five hypotheses were tested, FRQ as dependent variable was regressed with five independent variables represent $\mathrm{AC}$ size (ACSIZE), AC independence (ACINDE), AC meetings (ACMEET), AC experience (ACEXP), and the audit firm size as proxy for audit quality (ACQUAL). Five appropriate control 
variables were added to the study model represent, company size (FSIZE), company performance (FROE), company leverage (FLEV), company listing on other stock markets (FLIST), and the industry type (INDTYPE). To measure the FRQ, the author adopted the qualitative approach using checklist developed by Nijmegen Center for Economics (NiCE) with limited modification based on the new amendments of the financial reporting conceptual framework issued by IASB in 2018. To measure FRQ according to this comprehensive instrument, standardized scores for both qualitative characteristics was computed. The instrument comprises index of 21 items, each item is measured by 5 degree-scale, and the maximum total score for any company is totalling 105. The score for each company is calculated and divided by 121 to be measured as percentage represents the level of FRQ. The validity and reliability of the adopted instrument were tested using Cronbach's alpha and Krippendorff's alpha and the results of these tests were 0.75 and 0.79 respectively, which are above the required score 0.70 . This suggests that score of measuring FRQ is valid and reliable.

The study findings reveal that the level of FRQ on the study sample averaged $63 \%$ while the minimum and the maximum valued $40 \%$ and $86 \%$ respectively. Also, there is no difference between the level of FRQ based on fundamental qualitative characteristics only and based on enhancing qualitative characteristics only as they valued $65 \%$ and $64 \%$ respectively. These results suggest that more improvements of FRQ are needed by giving more attention to the IASB conceptual framework for financial reporting, and companies listed on GCC countries stock markets do not pay more attention to fundamental characteristics than enhancing characteristics. The average of $\mathrm{AC}$ size is about 4.5 members with minimum of 3 and maximum of 7 members. The average of $\mathrm{AC}$ independence is about $62 \%$ with minimum of $20 \%$ and maximum of $100 \%$. Regarding the AC financial and accounting expertise, the average is about $39 \%$ with minimum of $33 \%$ and maximum of $86 \%$. AC meetings are averaged about 7 meetings each year with minimum of 4 and maximum of 14. The results related to $\mathrm{AC}$ attributes are mostly consistent with the codes of corporate governance and the regulations of stock markets in the GCC countries, as the minimum of AC size not less 
than 3, members should be independent, at least one of them has financial expertise, and they meet at least 4 times a year. Only the independence level needs to be improved, as some $\mathrm{AC}$ members are executive. About $\mathbf{4 2 \%}$ of listed companies in the GCC countries stock market hire one of the big four audit firm while the remaining $58 \%$ hire auditor not from the big four, which indicates that the quality of external auditing. Also, about $18 \%$ of these companies are listed on other stock markets, as GCC countries stock markets regulations encourage companies to be listed in other stock markets. The results indicate that FRQ are positively and significantly associated with the four AC attributes and audit quality so, all the five null hypotheses are rejected, and the alternative hypotheses are accepted as there is a positive significant association between $F R Q$ as dependent variable and five independent variables named, ACSIZE, ACINDE, ACEXPE, ACMEET, and AUDQUL.

There are some limitations of the current study. First, the study sample includes companies only from four of the six GCC countries' stock markets, and it is recommended to be re-conducted with all six countries. Second, results are limited to the GCC context and could be re-conducted on other emerging markets. The findings of this study have wide implications to all stakeholders and stock markets for the role of AC attributes as internal corporate governance mechanism and external auditor as external corporate governance mechanism on improving FRQ. 


\section{REFERENCES}

Abernathy, J. L., Beyer, B., Masli, A., \& Stefaniak, C. M. (2015). How the source of audit committee accounting expertise influences financial reporting timeliness. Current Issues in Auditing, 9(1), P1-P9.

Akhtaruddin, M., \& Haron, H. (2010). Board ownership, audit committees' effectiveness and corporate voluntary disclosures. Asian Review of Accounting.

Al-Shaer, H., Salama, A., \& Toms, S. (2017). Audit committees and financial reporting quality: Evidence from UK environmental accounting disclosures. Journal of Applied Accounting Research, 18(1), 2-21. doi:10.1108/JAAR-10-2014-0114

Allegrini, M., \& Greco, G. (2013). Corporate boards, audit committees and voluntary disclosure: Evidence from Italian listed companies. Journal of Management \& Governance, 17(1), 187-216.

Alzoubi Ebraheem Saleem, S. (2019). Audit committee, internal audit function and earnings management: evidence from Jordan. Meditari Accountancy Research, 27(1), 72-90. doi:10.1108/MEDAR-06-2017-0160

Badolato, P. G., Donelson, D. C., \& Ege, M. (2014). Audit committee financial expertise and earnings management: The role of status. Journal of accounting economics, 58(2-3), 208-230.

Bajra, U., \& Čadež, S. (2018). Audit committees and financial reporting quality: The 8th EU Company Law Directive perspective. J Economic Systems, 42(1), 151-163.

Bamahros, H. M., \& Bhasin, M. L. (2016). Audit committee characteristics and unexpected accruals: an empirical study of Malaysia. Wulfenia, 23, 181-199.

Barth, M. E., Landsman, W. R., \& Lang, M. H. (2008). International accounting standards and accounting quality. Journal of accounting research, 46(3), 467-498. 
Beasley, M. S., Carcello, J. V., Hermanson, D. R., \& Neal, T. L. (2009). The audit committee oversight process. $J$ Contemporary Accounting Research, 26(1), 65-122.

Bedard, J., Chtourou, S. M., \& Courteau, L. (2004). The effect of audit committee expertise, independence, and activity on aggressive earnings management. Journsl of Auditing: A Journal of Practice Theory, 23(2), 13-35.

Bédard, J., \& Gendron, Y. (2010). Strengthening the financial reporting system: can audit committees deliver? International journal of auditing, 14(2), 174-210.

Beest, F. V., Braam, G., \& Boelens, S. (2009). Quality of Financial Reporting: measuring qualitative characteristics. 1-41.

Bruynseels, L., \& Cardinaels, E. (2014). The audit committee: Management watchdog or personal friend of the CEO? The accounting review, $89(1), 113-145$.

Bryce, M., Ali, M. J., \& Mather, P. R. (2015). Accounting quality in the pre-/post-IFRS adoption periods and the impact on audit committee effectiveness-Evidence from Australia. Pacific-Basin Finance Journal, 35, 163-181.

Carrera, N., Sohail, T., \& Carmona, S. (2017). Audit committees' social capital and financial reporting quality. Accounting Business Research, 47(6), 633-672.

Chariri, A., \& Januarti, I. (2017). Audit committee characteristics and integrated reporting: Empirical study of companies listed on the johannesburg stock exchange. European Research Studies Journal(4), 305-318.

Choi, J.-H., Kim, C., Kim, J.-B., \& Zang, Y. (2010). Audit office size, audit quality, and audit pricing. J Auditing: A Journal of practice theory, 29(1), 73-97.

Cooray, T., Gunarathne, A., \& Senaratne, S. (2020). Does corporate governance affect the quality of integrated reporting? Sustainability, 12(10), 4262. 


\section{Audit Committee Attributes, Audit Quality, and Financial Reporting Quality... Dr. Salah Abdel-Hafeez Mostafa Ali}

Davidson, R., Goodwin-Stewart, J., \& Kent, P. (2005). Internal governance structures and earnings management. journal of accounting and finance, 45(2), 241-267.

Dechow, P. M., \& Dichev, I. D. (2002). The quality of accruals and earnings: The role of accrual estimation errors. The accounting review, 77(s-1), 35-59.

Dhaliwal, D., Naiker, V., \& Navissi, F. (2010). The association between accruals quality and the characteristics of accounting experts and mix of expertise on audit committees. J Contemporary Accounting Research, 27(3), 787-827.

Dilling, P. F., \& Caykoylu, S. (2019). Determinants of companies that disclose high-quality integrated reports. Sustainability, $11(13), 3744$.

Dyreng, S. D., Hillegeist, S. A., \& Penalva, F. (2020). Earnings Management to Avoid Debt Covenant Violations and Future Performance. European Accounting Review, 1-33. doi:10.1080/09638180.2020.1826337

Francis, J. R., \& Yu, M. D. (2009). Big 4 office size and audit quality. The accounting review, 84(5), 1521-1552.

Garven, S. (2015). The effects of board and audit committee characteristics on real earnings management: Do boards and audit committees play a role in its promotion or constraint? Academy of Accounting Financial Studies Journal, 19(1), 1-7.

Gaynor, L. M., Kelton, A. S., Mercer, M., \& Yohn, T. L. (2016). Understanding the relation between financial reporting quality and audit quality. J Auditing: A Journal of practice theory, 35(4), 1-22.

Ghafran, C., \& O'Sullivan, N. (2013). The governance role of audit committees: Reviewing a decade of evidence. International Journal of Management Reviews, 15(4), 381-407.

Greco, G. (2011). Determinants of board and audit committee meeting frequency: Evidence from Italian companies. Managerial Auditing Journal, 26(3), 208-229. doi:10.1108/02686901111113172 
Habbash, M., \& Alagla, S. (2015). Audit committee effectiveness and audit quality: Evidence from Saudi Arabia. International Journal of Management Applied Science, 1(7), 5-14.

Hamdan, A. M. M. J. (2020). Audit committee characteristics and earnings conservatism in banking sector: empirical study from GCC. Afro-Asian Journal of Finance \& Accounting, 10(1), 1-23.

Hasan, M. T., Molla, M. S., \& Khan, F. (2019). Effect of board and audit committee characteristics on profitability: Evidence from pharmaceutical and chemical industries in Bangladesh. Finance Economics Review, 1(1), 64-76.

Hasan, S., Kassim, A. A. M., \& Hamid, M. A. A. (2020). The Impact of Audit Quality, Audit committee and Financial Reporting Quality: Evidence from Malaysia. International Journal of Economics Financial Issues, 10(5), 272-281.

Hayes, R. M. (2014). Discussion of "Audit committee financial expertise and earnings management: The role of status" by Badolato, Donelson, and Ege (2014). Journal of accounting economics, 58(2-3), 231-239.

Hunton, J. E., Libby, R., \& Mazza, C. L. (2006). Financial reporting transparency and earnings management (retracted). The accounting review, $81(1)$, 135-157.

Inaam, Z., Khmoussi, H., \& Fatma, Z. (2012). Audit quality and earnings management in the Tunisian context. International Journal of Accounting Financial Reporting, 2(2), 17.

Kamolsakulchai, M. (2015). The impact of the audit committee effectiveness and audit quality on financial reporting quality of listed company in stocks exchange of Thailand. Review of Integrative Business Economics Research, 4(2), 328.

Khlif, H., \& Samaha, K. (2016). AC activity and internal control quality in Egypt: Does external auditor's size matter? Managerial Auditing Journal, 31(3), 269-289. doi:10.1108/MAJ-08-2014-1084

Kibiya, M., Ahmad, A., Amran, N. J. T. E. P. o. S., \& Sciences, B. (2016). Audit committee characteristics and financial reporting quality: Nigerian non-financial listed firms. Selection and peer-review under responsibility of the Organizing Committee of the conference, 753-759. 


\section{Audit Committee Attributes, Audit Quality, and Financial Reporting Quality... Dr. Salah Abdel-Hafeez Mostafa Ali}

Krishnan, J. (2005). Audit committee quality and internal control: An empirical analysis. The accounting review, 80(2), 649-675.

Kusnadi, Y., Leong, K. S., Suwardy, T., \& Wang, J. (2016). Audit committees and financial reporting quality in Singapore. Journal of business ethics, 139(1), 197-214.

Lin, J. W., \& Hwang, M. I. (2010). Audit quality, corporate governance, and earnings management: A meta-analysis. International journal of auditing, 14(1), 57-77.

Lin, J. W., Li, J. F., \& Yang, J. S. (2006). The effect of audit committee performance on earnings quality. Managerial Auditing Journal, 21(9), 921-933.

Miko, N. U., \& Kamardin, H. (2015). Impact of audit committee and audit quality on preventing earnings management in the pre-and postNigerian corporate governance code 2011. Procedia-Social Behavioral Sciences, 172, 651-657.

Mohammad, A. J., \& Ahmed, D. M. (2017). The Impact of audit committee and External Auditor Characteristics on Financial Reporting Quality among Malaysian Firms. Research Journal of Finance Accounting, 8(13), 9-16.

Mwangi, A. K. (2018). Effect of Audit Committee Characteristics on Quality of Financial Reporting among Non-Commercial State Corporations in Kenya. (PhD), JKUAT,

Oji, O., \& Ofoegbu, G. N. (2017). Effect of audit committee qualities on financial reporting of listed companies in Nigeria: A perspective study. International Journal of Scientific Research Publications, 7(10), 1-10.

Oussii Ahmed, A., \& Boulila Taktak, N. (2018). Audit committee effectiveness and financial reporting timeliness: The case of Tunisian listed companies. African Journal of Economic and Management Studies, 9(1), 34-55. doi:10.1108/AJEMS-11-2016-0163

Persons, O. S. (2009). Audit committee characteristics and earlier voluntary ethics disclosure among fraud and no-fraud firms. International journal of disclosure governance, 6(4), 284-297. 
Pillai, R., \& Al-Malkawi, H.-A. N. (2018). On the relationship between corporate governance and firm performance: Evidence from GCC countries. Research in International Business Finance, 44, 394-410.

Pomeroy, B., \& Thornton, D. B. (2008). Meta-analysis and the accounting literature: The case of audit committee independence and financial reporting quality. J European Accounting Review, 17(2), 305330.

Qinghua, W., Pingxin, W., \& Junming, Y. (2007). Audit committee, board characteristics and quality of fi nancial reporting: An empirical research on Chinese securities market. J Frontiers of Business Research in China, 1(3), 385-400.

Rainsbury, E. A., Bradbury, M., \& Cahan, S. F. (2009). The impact of audit committee quality on financial reporting quality and audit fees. Journal of Contemporary Accounting Economics, 5(1), 20-33.

Setiany, E., Hartoko, S., Suhardjanto, D., \& Honggowati, S. (2017). Audit committee characteristics and voluntary financial disclosure. Review of Integrative Business Economics Research, 6(3), 239.

Shankaraiah, K., \& Amiri, S. M. S. J. (2017). Audit committee quality and financial reporting quality: a study of selected Indian companies. Journal of Accounting Business Dynamics, 4(1), 1-18.

Sharhan, A. A., \& Bora, C. (2020). Effect of audit committee characteristics on Audit Quality: A Critical Literature Review. Journal of Advanced Research in Economics Administrative Sciences, 1(1), 1-12.

Shubita Moade, F. (2015). The impact of income smoothing on earnings quality in emerging markets: Evidence from GCC markets. Journal of Accounting in Emerging Economies, 5(3), 299-324. doi:10.1108/JAEE04-2011-0011

Soliman, M. M., \& Ragab, A. A. (2014). Audit committee effectiveness, audit quality and earnings management: an empirical study of the listed companies in Egypt. Research journal of finance \& accounting, 5(2), 155166.

Sultana, N., Singh, H., \& Van der Zahn, J. L. M. (2015). Audit committee characteristics and audit report lag. International journal of auditing, 19(2), 72-87. 


\section{Audit Committee Attributes, Audit Quality, and Financial Reporting Quality... Dr. Salah Abdel-Hafeez Mostafa Ali}

Tanyi, P. N., \& Smith, D. B. (2015). Busyness, expertise, and financial reporting quality of audit committee chairs and financial experts. $J$ Auditing: A Journal of practice theory, 34(2), 59-89.

Tasios, S., \& Bekiaris, M. (2012). Auditor's perceptions of financial reporting quality: the case of Greece. International Journal of Accounting Financial Reporting, 2(1), 57.

Turley, S., \& Zaman, M. (2007). Audit committee effectiveness: informal processes and behavioural effects. Accounting, Auditing \& Accountability Journal, 20(5), 765-788. doi:10.1108/09513570710779036

Umobong, A. A., \& Ibanichuka, E. (2017). Audit committee attributes and financial reporting quality of food and beverage firms in Nigeria. International Journal of Innovative Social Sciences Humanities Research, 5(2), 1-13.

Watts, R. L., \& Zimmerman, J. L. (1986). Positive accounting theory: Prentice-Hall Inc.

Xie, B., Davidson III, W. N., \& DaDalt, P. J. (2003). Earnings management and corporate governance: the role of the board and the audit committee. Journal of corporate finance, 9(3), 295-316.

Yang, J. S., \& Krishnan, J. (2005). Audit committees and quarterly earnings management. International journal of auditing, 9(3), 201-219. 